\title{
PENGARUH GAYA KEPEMIMPINAN DAN TINGKAT KEDISIPLINAN KERJA TERHADAP KINERJA KARYAWAN DI UNIT PT.BANK BTPN SYARI'AH,TBK CABANG SERANG
}

\author{
Listiawati, Angrian Permana dan Isma Khoirunnisa \\ Fakultas Ekonomi dan Bisnis, Universitas Bina Bangsa, Serang \\ Email: listy234@gmail.com,mr.angrianpermana@gmail.com, \\ Ismakhoirunnisa123@gmail.com
}

\begin{abstract}
The purpose of this study is to examine the influence of leadership style and the level of discipline on the performance of employees in the Unit PT.Bank Btpn Syari'ah, Tbk Serang Branch. The research method used is quantitative by using Descriptive Approach method with the questionnaire as a research instrument.That simultaneously there is influence between Leadership Style and Discipline to Employee Performance. value of correlation coefficient between Leadership Style and Discipline to Employee Performance of 0908 (very strong). the value of determination coefficient of 0.824 , meaning Leadership Style (x1) and Discipline (x2) contributed 82.4\% to Employee Performance (Y), while the remaining $17.6 \%$ influenced other variables not described in this study.
\end{abstract}

Keywords: Leadership Style, Discipline, Employee Performance

Abstrak: Tujuan dari penelitian ini adalah untuk menguji pengaruh gaya kepemimpinan dan tingkat kedisiplinan terhadap kinerja karyawan di Unit PT.Bank Btpn Syari'ah,Tbk Cabang Serang. Metode penelitian yang digunakan adalah kuantitatif dengan menggunakan metode pendekatan Deskriptif Asosiatif dengan kuesioner sebagai instrumen penelitian. Bahwa secara simultan terdapat pengaruh antara Gaya Kepemimpinan dan Kedisiplinan terhadap Kinerja Karyawan. nilai koefisien korelasi antara Gaya Kepemimpinan dan Kedisiplinan terhadap Kinerja Karyawan sebesar 0.908 (sangat kuat). nilai koefisien determinasi sebesar 0,824, artinya Gaya Kepemimpinan ( $\mathrm{x}_{1}$ ) dan Kedisiplinan ( $\left.\mathrm{x}_{2}\right)$ memberikan kontribusi sebesar 82,4\% terhadap Kinerja Karyawan (Y), sedangkan sisanya $17,6 \%$ dipengaruhi variabel lain yang tidak dijelaskan dalam penelitian ini.

Kata Kunci: Gaya Kepemimpinan, Kedisiplinan, Kinerja Karyawan

\section{PENDAHULUAN}

Seiring dengan perkembangan teknologi yang semakin maju masa ke masa, membuat persaingan dalam dunia kerja meningkat. Hal ini dikarenakan adanya globalisasi dan medernisasi. Selain itu, perkembangan usaha yang pesat juga berdampak pada tingginya persaingan antar perusahaan sejenis. Faktor manusia memegang peranan paling dominan diantara faktor-faktror lain, sehingga memungkinkan suatu perusahaan akan menghadapi persaingan yang semakin ketat. Dengan adanya persaingan ini memaksa perusahaan terus mengembangkan Sumber Daya Manusia yang dimiliki. SDM yang baik dilakukan sebuah perusahaan adalah SDM yang memenuhi kinerja yang baik, maju mundurnya sebuah perusahaan tergantung dari kinerja karyawan. 
Menurut Robbins (2008) Kinerja Karyawan yaitu suatu hasil yang dicapai oleh karyawan dalam pekerjaannya menurut kriteria tertentu yang berlaku untuk suatu pekerjaan. Dalam hal ini kinerja karyawan menunjukan pada kemampuan karyawan dalam melaksanakan keseluruhan tugas-tugas yang menjadi tanggung jawabnya. Tugas-tugas tersebut biasanya berdasarkan indikator-indikator keberhasilan yang sudah diterapkan. Kinerja juga memilikiperananyang penting, erat kaitannya dengan gaya kepemimpinan dan kedisiplinan. Apabila semua varibel bersifat positif, maka akan tercipta pula sistem yang baik untuk kelangsungan dankemajuanpadasuatu organisasi, perusahaan atau instansi tersebut.

Salah satu faktor menentukan kinerja adalah gaya kepemimpinan yang dijalankan oleh seorang pemimpin. Menurut Tjipto (2006:161) Gaya kepemimpinan adalah suatu cara yang dipergunakan pemimpin dalam beinteraksi dengan bawahannya. Maka dalam hal ini Gaya kepemimpinan merupakan cara berprilaku seorang pemimpin terhadap berinteraksin atau beradaptasi dengan bawahannya, karena keberhasilannya suatu perusahaan bagaimana cara bersikap seorang pemimpin demi menghidupkan organisasi dalam suatu perusahaan, pemimpin juga harus bisa merangkul bawahannya bekerja dengan tim agar semua tujuan dapat tercapai.

Faktor lain yang berpengaruh dalam upaya untuk meningkatkan kinerja karyawan bisa dilihat dari tingkat kedisiplinan. Menurut Terry (dalam Tohardi 2002) disiplin merupakan alat penggerak karyawan. Agar tiap pekerjaan dapat berjalan dengan lancar, maka harus diusahakan agar ada disiplin yang baik. Maka dalam hal ini kedisiplinan adalah faktor yang sangat berpengaruh untuk suatu hasil pekerjaan yang karyawan kerjakan, dari penjelasan Terry dapat disimpulkan bahwa produktivitas kerja pegawai dalam suatu organisasi sangat dipengaruhi oleh disiplin pegawai. Apabila diantara pegawai sudah tidak menghiraukan kedisiplinan kerja, maka dapat dipastikan produktivitas kerja akan menurun.

BANK BTPN Syari'ah,Tbk merupakansalah satu perusahaan perbankan dansebagai perpanjangan tangan dari Pt. Bank Btpn Syari' ah Kantor pusat Jakarta. BTPN adalah bank devisa yang memfokuskan diri untuk melayani dan memberdayakan segmen masyarakat berpendapat rendah yang terdiri dari pensiunan, pelaku usaha micro, kecil dan menegah (UMKM), Serta komunitas prasejahtera produktif (mass market).

Permasalahan dalam penelitian ini adalah: (1) Banyaknya kompetitor yang bergerak dibidang yang sama, pemberian modal usaha micro; (2) Dalam memberikan pelayanan kepada nasabah, masih terdapat hambatan yang dihadapi; (3) Pemimpin dalam penerapan kedisiplinan masil belum sesuai dengan keadaan karyawan, sehingga akan menghambat dalam pencapaian tujuan perusahaan; (4) Adanya penyalahgunaan pemberian modal yang kita berikan kepada nasabah, digunakan untuk keperluan pribadi bukan digunakan untuk modal usaha; (5) Pelaksanaan kegiatan sore hari sering tidak sesuai dengan jadwal pelaksanaan yang telah ditentukan pada awal hari, karena terdapat beberapa hal kendala yang terjadi dilapangan; (6) Masih minimnya jumlah SDM (Sumber Daya Manusia), banyaknya karyawan lama yang mengunduran diri sehinggan merekrut karyawan baru yang masih memerlukan bimbingan sehingga waktu yang seharusnya untuk mengerjakan kerjaan yang lain terbatas karena untuk membimbing karyawan yang baru.

\section{KAJIAN TEORI}

Gaya Kepemimpinan. Gaya kepemimpinan adalah prilaku atau cara yang dipilih dan dipergunakan pemimpin dalam mempengaruhi pikiran, perasaan, sikap, dan prilaku para 
anggota organisasi atau bawahan. Hubungan pemimpin dan bawahan dapat diukur melalui penilain pekerja terhadap gaya kepemimpinan para pemimpin dalam mengarahkan dan membina para bawahannya untuk melaksanakan pekerjaan.

Terdapat Lima gaya kepemimpinan Menurut Siagian (2002), Yaitu: Pertama. Tipe Pemimpin Otokratik. Seorang pemimpin yang otokratik ialah seorang pemimpin yang: (a) Menganggap organisasi sebagai milik pribadi; (b) Mengidentikan tujuan pribadi dengan tujuan organisasi; (c) Menganggap bahwa sebagai alat semata-mata; (d) Tidak mau menerima kritik, saran dan pendapat; (e) Terlalu tergantung pada kekuasaan formalnya; (f) Dalam tindakannya penggeraknya sering mempergunakan approach yang mengandung unsur paksaan pada punitif (bersifat menghukum). Kedua. Tipe pemimpin yang militeristik. Perlu diperhatikan terlebih dahulu bahwa yang dimaksud seorang pemimpin tipe militeristik berada dengan seorang pemimpin modern. Seorang pemimpin yang bertipe militeristik ialah seorang pemimpin yang memiliki sifat-sifat: (a) Dalam menggerakan bawahannya sistem perintah yang sering dipergunakan; (b) Dalam menggerakan bawahannya senang bergantung pada pangkat dan jabatan; (c) Senang kepada formalitas yang berlebih-lebihan; (d) Menuntut disiplin yang tinggi dan kaku dari bawahannya. Ketiga. Tipe pemimpin yang paternalistic: (a) Menganggap bahwa sebagai manusia yang tidak dewasa; (b) Bersikap terlalu melindungi; (c) Jarang memberikan kesempatan kepada bawahannya untuk mengambil keputusan; (d) Jarang memberikan kesempatan kepada bawahann untuk mengambil inisiatif; (e) Jarang memberikan kesempatan kepada bawahan untuk mengembangkan daya kreasi dan fantasi; (f) Sering bersikap mau tahu. Keempat. Tipe pemimpin yang karismatik. Harus diakui bahwa untuk keadaan tentang seorang pemimpin yang demikian sangat diperlukan, akan tetapi sifatnya sangat negatif mengalahkan yang positif. Kelima. Tipe pemimpin yang demokratik. Pengetahuan tentang kepemimpinan telah membuktikan bahwa tipe pemimpin yang demokratis lah yang paling tepat untuk organisasi modern karena: (a) Ia senang menerima saran, pendapat bahkan kritikan dari bawahannya; (b) Selalu berusaha mengutamakan kerjasama tim dalam usaha mencapai tujuan; (c) Selalu berusaha menjadikan lebih sukses dari padanya; (d) Selalu berusaha mengembangkan kapasitas diri pribadinya sebagai pemimpin.

Tingkat Kedisiplinan. Disiplin merupakan bentuk pelatihan yang menegakan peraturanperaturan, penyusaian diri terhadap tiap individu terhadap segala sesuatu yang ditetapkan kepadanya, akan menciptakan suatu masyarakat yang tertib dan bebas dari kekacauankakacauan. Demikian juga kehidupan dalam suatu perusahaan akan sangat membutuhkan ketaatan dari anggota-anggotanya pada peraturan dan ketentuan yang berlaku pada perusahaan tersebut. Dengan kata lain, disiplin kerja pada karyawan sangat dibutuhkan, karena apa yang menjadi tujuan perusahaan akan sukar dicapai bila tidak ada disiplin kerja.

Macam-macam Disiplin Kerja. Ada 2 bentuk disiplin kerja, yaitu disiplin preventif, dan disiplin korektif. Pertama. Disiplin Preventif. Disiplin Preventif adalah suatu upaya untuk menggerakan pegawai mengikuti dan mematuhi pedoman kerja, aturan-aturan yang telah digariskan oleh perusahaan. Tujuan dasarnya adalah untuk menggerakan pegawai berdisiplin diri. Dengan cara preventif, pegawai dapat memelihara dirinya terhadap peraturan-peraturan perusahaan. 
Pemimpin perusahaan mempunyai tanggung jawab dalam membangun iklim organisasi dengan disiplin preventif. Begitu pula pegawai harus dan wajib mengetahui, memahami semua pedoman kerja serta peraturan-peraturan yang ada dalam organisasi. Disiplin Preventif merupakan suatu sistem yang berhubungan dengan kebutuhan kerja semua bagian sistem yang ada dalam organisasi. Jika sistem organisasi baik, maka diharapkan akan lebih mudah menegakan disiplin kerja.

Kedua. Disiplin Korektif. Disiplin Korektif adalah suatu upaya menggerakan pegawai dalam menyatukan suatu peraturan dan mengarahkan untuk tetap mematuhi peraturan sesuai dengan pedoman yang berlaku pada perusahaan.

Pada disiplin korektif, pegawai yang melanggar disiplin perlu diberikan sanksi sesuai dengan peraturan yang berlaku. Tujuan pemberian sanksi adalah untuk memperbaiki pegawai pelanggar, memelihara peraturan yang berlaku, dan memberikan pelajaran kepada pelanggar.

Disiplin korektif memerlukan perhatian khusus dan proses prosedur yang seharusnya. Hal ini sesuai dengan pendapat Keith Davis (1985:367) mengemukakan bahwa: Korektif memerlukan perhatian proses yang seharusnya, yang berarti bahwa prosedur harus menunjukan pegawai yang bersangkutan benar-benar terlibat. Keperluan proses yang seharusnya itu dimaksudkan adalah pertama, suatu prasangka yang tak bersalah sampai pembuktian pegawai berperan dalam pelanggaran. Kedua, hak untuk didengar dalam beberapa kasus terwakilkan oleh pegawai lain. Ketiga, disiplin itu dipertimbangkan dalam hubungannya dengan keterlibatan pelanggaran.

Faktor-faktor Yang Mempengaruhi Disiplin Kerja. Asumsinya bahwa pemimpin mempunyai pengaruh lamgsung atas sikap kebiasaan yang diperoleh kryawan. Kebiasaan itu ditentukan oleh pemimpin, baik dengan iklim atau suasana kepemimpinan maupun melalui contoh diri pribadi. Karena itu, untuk mendapat disiplin yang baik, maka pemimpin harus memberikan kepemimpinan yang baik pula. Faktor yang mempengaruhi disiplin pegawai antara lain:

a) Besar kecilnya pemberian kompensasi. Besar kecilnya kompensasi dapat mempengaruhi tegaknya disiplin. Para karyawan akan mematuhi segala peraturan yang berlaku, bila ia merasa mendapat jaminan balas jasa yang setimpal dengan jerih payahnya yang telah dikontribusikan bagi perusahaan.

b) Ada tidaknya keteladana pemimpin dalam peusahaan. Keteladana pemimpin sangat pening sekali, karena dalam lingkungan perusahaan, semua karyawan akan selalu memerhatikan bagaimana pemimpin dapat menegakan disiplin dirinya dan bagaimana ia dapat mengendalikan dirinya dari ucapan, perbuatan, dan sikap yang dapat merugikan aturan disiplin yang sudah ditetapkan.

c) Ada tidaknya aturan pasti yang dapat dijadikan pegangan. Pembinaan disiplin tidak akan dapat terlaksana dalam perusahaan, bila tidak ada aturan tertulis yang pasti untuk dapat dijadikan pegangan bersama. Disiplin tidak mungkin ditegakan bila peraturan yang dibuat hanya berdasarkan intruksi lisan yang dapat berubah-ubah sesuai dengan kondisi dan situasi.

d) Keberanian pimpinan dalam mengambil keputusan. Bila ada seseorang karyawan yang melanggar disiplin, maka perlu ada keberanian pemimpin unuk mengambil tindakan yang sesuai denga tingkat pelanggaran yang dibuatnya. Dengan adanya tindakan terhadap pelangar disiplin, sesuai dengan sanksi yang ada, maka semua karyawan akan 
merasa terlindungi, dalam siyuasi demikian, maka semua karyawan akan benar-benar terhindar dari sikap sembrono, asal jadi seenaknya sendiri dalam perusahaan.

e) Ada tidaknya pengawasan pimpinan. Dalam setiap kegiatan yang dilakukan oleh perusahaan perlu ada pengawasan, yang akan mengarahkan para karyawan agar dapat melaksanakan pekerjaan dengan tepat dan sesuai dengan yang telah diterapkan. Namun sudah menjadi tabiat manusi pula bahwa mereka selalu ignin bebas, tanpa terikat atau diikat oleh perauran apapun juga.

f) Ada tidaknya perhatian kepada para karyawan. Karyawan adalah manusia yang mempunyai perbedaan karakter antara yang satu dengan yang lain. Seorang karyawan tidak hanya puas dengan penerimaan kompensasi yang tinggi, pekerjaan yang menantang, tetapi juga mereka masih membutuhkan perhatian yang besar dari pimpinanya sendiri. Keluhan dan kesulitan mereka ingin didengar, dan dicarikan jalan keluarnya, dan sebagainya. pimpinan yang berhasil member perhatian yang besar kepada para karyawan akan dapat menciptakan disiplin kerja yang baik.

g) Diciptakan kebiasaan-kebiasaan yang mendukung tegaknya disiplin. Kebiasaankebiasaan positif itu antara lain: (a) Saling menghormati, bila ketemu di lingkungan pekerjaan; (b) Melontarkan pujian sesuai dengan tempat dan waktunya, sehingga para karyawan akan turut merasa bangga dengan pujian tersebut; (c) Sering mengikut sertakan karyawan dalam pertemuan-pertemuan, apalagi pertemuan yang berkaitan dengan nasib dan pekerjaan mereka; (d) Member tahu bila ingin meninggalkan tempat kepada rekan sekerja, dengan menginformasikan, kemana dan untuk uusan apa, walaupun kepada bawahan sekalipun.

\section{Kerangka Konseptual}

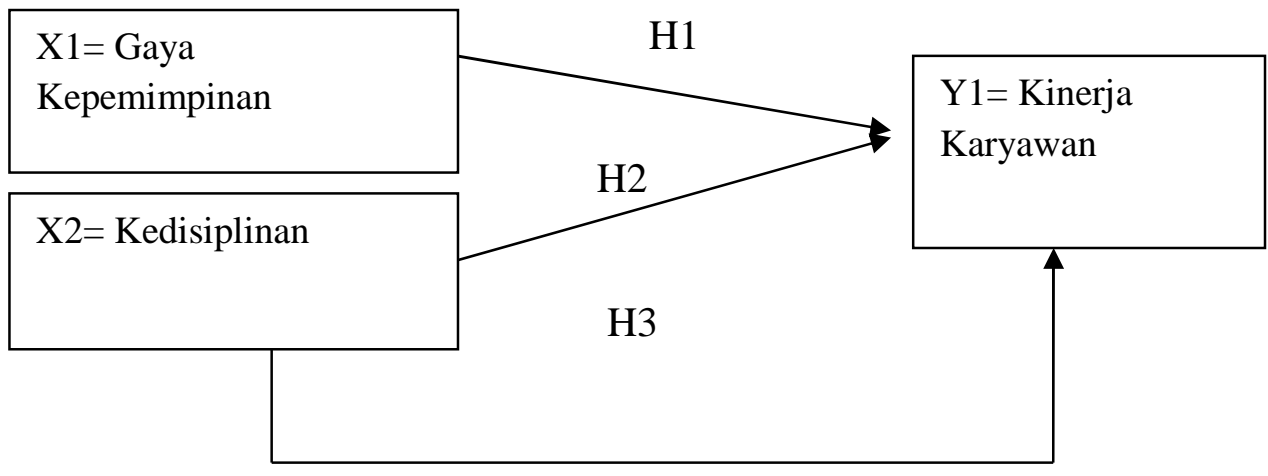

Gambar 1. Kerangka Konseptual

Hipotesis Penelitian. Berdasarkan pada landasan teori dan kerangka pemikiran diatas, maka hipotesis dalam penelitian ini adalah sebagai berikut:

$\mathrm{H}_{1}$ : Diduga Gaya kepemimpinan berpengaruhterhadap kinerja karyawan pada PT.BANK BTPN Syari'ah,Tbk Cabang Serang

$\mathrm{H}_{2}$ : Diduga Tingkat Kedisiplinan berpengaruh terhadap kinerja karyawan pada PT.BANK BTPN Syari'ah,Tbk Cabang Serang

$\mathrm{H}_{3}$ :Diduga kepemimpinan dan Tingkat Kedisiplinan secara bersama-sama mempunyai pengaruh terhadap kinerja pegawai pada PT.BANK BTPN Syari'ah,Tbk Cabang Serang. 


\section{METODE}

Metode yang digunakan dalam penelitian ini adalah Kuantitatif, dengan pendekatan analisa Deskriptif Asosiatif.

Dalam penelitian ini yang menjadi lokasi penelitian adalah karyawan pada PT.BANK BTPN Syari'ah,Tbk Cabang Serang. Pada 4 Cabang PT.BANK BTPN Syari'ah,Tbk Cabang Serang Diantaranya yaitu: (1) PT.BANK BTPN Syari'ah,Tbk Cabang Serang di MMS Ciruas yang berlokasi (Perum Puri Anggrek Gang Flamboyan Blok A4 No.7 Kel.Kalodran Kec.Walantaka); (2) PT.BANK BTPN Syari'ah,Tbk Cabang Serang di MMS Cipocok Jaya yang berlokasi ( Lingk.Cipocok tegal Rt 01 Rw 06 Kel.Cipocok Jaya Kec.Cipocok Jaya); (3) PT.BANK BTPN Syari'ah,Tbk Cabang Serang di MMS Baros yang berlokasi (Kp.Waru Masjid Rt.14 Rw.04 Kel.Kemanisan Kec.Baros) dan (4) PT.BANK BTPN Syari'ah,Tbk Cabang Serang di MMS Kasemen yang berlokasi (Komp Bumi Serang Permai Blok C4 No.8 Kasemen serang-banten).

Teknik Pengumpulan Data. Pertama. Data sekunder. Penelitian Kepustakaan (Library Reasearch) yaitu pengumpulan data yang dilakukan dengan jalan membaca dan mempelajari literatur-literatur, laporan atau tulisan-tulisan ilmiah, catatan kuliah dan agenda atau file perpustakaan yang semuanya memiliki kaitan langsung dengan masalah yang diteliti. Kedua. Data Primer. Studi Lapangan (field Research) diantaranya yaitu: (a) Pengamatan (Observasi), yaitu teknik pengumpulan data dengan cara penelitian dan pengamatan langsung pada objek yang di teliti; (b) Angket (Quesioner), yaitu teknik pengumpulan data yang dilakukan dengan cara memberi seperangkat pertanyaan tertulis kepada responden untuk di jawaban; (c) Wawancara, dan (d) Dokumentasi.

Populasi dan Sampel. Populasi adalah wilayah generasi yang terdiri atas objek/subjek yang mempunyai kualitas dan karakteristik tertentu yang ditetapkan oleh peneliti untuk dipelajari dan kemudian ditarik kesimpulannya. Populasi dalam penelitian ini adalah karyawan pada PT.BANK BTPN Syari'ah,Tbk Cabang Serang dibeberapa cabang diantaranya sebagai berikut: (1) MMS Ciruas sebanyak 9 karyawan; (2) MMS Cipocok Jaya sebanyak 8 karyawan; (3) MMS Baros sebanyak 9 karyawan, dan (4) MMS Kasemen sebanyak 9 karyawan. Jadi jumlah populasi dalam penelitian pada PT.BANK BTPN Syari'ah,Tbk Cabang Serang sebanyak 35 Karyawan.

Sampel. Sampel adalah sebagian dari jumlah dan karakteritik yang dimiliki oleh populasi tersebut. Apa yang dipelajari dari sampel itu, kesimpulannya akan diberlakukan untuk populasi. Untuk itu sampel yang di ambil dari populasi harus betul-betul refresentatif (mewakili). Sampel yang baik adalah sampel yang mewakili karakteristik dari populasi sehingga kesimpulan yang diperoleh dari data sampel dapat berlaku pada populasi dengan tingkat kesalahan yang dapat diperhitungkan. Adapun sampel dalam penelitian ini adalah sampel jenuh dimana jumlah sampel sama dengan jumlah populasi yaitu sebanyak 35 orang. Sampel jenuh merupakan teknik penentuan sampel bila semua anggota populasi digunakan sebagai sampel, hal ini sering dilakukan bila jumlah populasi relatif kecil.

Variabel Penelitian dan Definisi Operasional Variabel. Penelitian merupakan kegiatan dilakukan untuk mendapatkan kebeneran atau fakta, yang dilakukan dengan mengumpulkan dan menganalisis data secara teliti, jelas, serta sistematis, dan dapat dipertanggung jawabkan atau dapat diuji kebenarannya (Fedinand, 2006). Untuk itu dalam 
proses penelitian perlu menggunakan metode yang biasa disebut dengan metode penelitian. Metode penelitian adalah cara-cara ilmiah untuk mencapai kebenaran ilmiah dengan langkah-langkah yang relevan terhadap masalah yang dirumuskan (Ferdinand, 2006).

1. Variabel Penelitian. Variabel penelitian adalah ubahan yang memiliki variasi nilai (Ferfinand, 2006). Ubahan disini adalah konsep abstrak yang telah diubah dengan menyebutkan dimensi tertentu yang dapat diukur. Dalam penelitian ini menggunakan dua Variabel yaitu: (1) Variabel Terikat (Dependent Variable). Dalam penelitian ini menjadi variabel terikat adalah Kinerja Karyawan (Y). (2) Variabel bebas (Independent Variable). Dalam penelitian ini yang menjadi variabel bebas adalah Gaya Kepemimpinan (X1), dan Kedisiplinan (X2).

2. Definisi Operasional Variabel. Menurut Widayat dan Amirullah (dalam Purnamasari, 2008) definisi operasional variabel merupakan suatu definisi yang diungkapkan secara jelas dari masing-masing variabel dalam penelitian, dan dijabarkan dalam indikatorindikator. Indikator adalah dimensi tertentu dari suatu konsep yang dapat diukur (Widiyanto, 2008). Sesuai dengan definisi variabel-variabel penelitian yang telah dideskripsikan dalam tinjaun pustaka, dan sesuai dengan pengukuran variabel peneliian menurut kaidah atau skala ukuran yang lazim diterima secara akademis, maka definisi operasional variabel adalah sebagai berikut:

1) Kinerja Karyawan (Y). kinerja merupakan gambaran mengenai tingkat pencapaian pelaksanaan suatu program kegiatan atau kebijakan dalam mewujudkan sasaran, tujuan, visi, dan misi organisasi yang dituangkan melalui perencanaan strategis suatu organisasi (Moeheriono, 2010:60).

Indikator dari Kinerja Karyawan adalah sebagai berikut: (a) Kualitas; (b) Kuantitas; (c) Ketepatan Waktu; (d) Efektifitas; (e) Kemandirian

2) Gaya Kepemimpinan (X1). Gaya kepemimpinan adalah prilaku atau cara yang dipilih dan dipergunakan pemimpin dalam mempengaruhi pikiran, perasaan, sikap, dan prilaku para anggota organisasi atau bawahan. Hubungan pemimpin dan bawahan dapat diukur melalui penilain pekerja terhadap gaya kepemimpinan para pemimpin dalam mengarahkan dan membina para bawahannya untuk melaksanakan pekerjaan. Indikator Gaya Kepemimpinan: (a) Komunikasi; (b) Motivasi; (c) Menggerakan; (d) Tegas; (e) Pengambilan Keputusan

3) Kedisiplinan. Secara etimologis, disiplin berasal dari bahasa inggris Disciple yang berarti "pengikut", atau "penganut", "latihan", dan sebagainya. Menurut Hartatik (2014:182) disiplin merupakan suatu keadaan tertentu dimana orang-orang yang bergabung dalam organisasi tunduk pada peraturan-peraturan yang ada dengan rasa senang hati, sedangkan kerja adalah segala aktivitas manusia yang dilakukan untuk mencapai tujuan yang telah ditetapkan.

Indikator Kedisiplinan: (a) Toleransi terhadap tindakan beresiko; (b) Dukungan Manajemen; (c) Integritas; (d) Inisiatif Individu.

Analisis Data. Teknik pengumpulan data dalam penelitian dilakukan dengan instrument yang disusun berbentuk kuesioner yang diisi oleh para responden.Kuesioner diberikan kepada Karyawan PT.BANK BTPN Syari'ah,Tbk Cabang Serang, pada saat penelitian berlangsung. Analisis data hasil penelian dilakukan dengan cara memberi nilai pada masing-masing jawaban responden. Skala Likert digunakan untuk mengukur sikap, pendapat dan presepsi seseorang atau kelompok orang tentang fenomena sosial. 
Data yang berhasil dikumpulkan selanjutnya diolah dan dianalisis tahap demi tahap kemudian data diperoleh setelah diklasifikasikan sesuai dengan kelompoknya ditabulasikan dalam bentuk tabel.

Metode Analisis Data. Pertama. Uji Instumen: (a) Uji Validitas ; (b) Reliabilitas. Kedua. Uji Asumsi Klasik: (a) Uji Normalitas; (b) Uji Multikolinnieritas; (c) Uji Heteroskedastisitas. Ketiga. Uji Hipotesis: (a) Uji T; (b) Uji F; (c) Koefisien Korelasi Sederhana; (d) koefisien korelasi berganda; (e) Korelasi determinasi Parcial; (f) Korelasi determinasi Saimultan.

Model Analisis ini dipilih untuk mengetahui besarnya pengaruh variabel-variabel bebas terhadap kinerja kerja karyawan, baik secara bersama-sama, maupun secara parsial.

Pengujian hipotesis atas regresi dan korelasi digunakan dengan alat analisis berikut: (a) Pengujian Korelasi secara parsial (Uji T); (b) Pengujian secara simultan dengan uji serempak (Uji F); (c) Koefisien Determinasi $\left(\mathrm{R}^{2}\right)$.

\section{HASIL DAN PEMBAHASAN}

Data yang digunakan dalam penelitian ini adalah data primer, yaitu data yang diperoleh secara langsung dari objek penelitian. Cara penarikannya dengan menggunakan kuesioner yang dibagikan kepada responden yang bertindak sebagai sampel. Responden dalam penelitian ini sebanyak 35 orang. Kuesioner telah diisi oleh 35 karyawan yang menjadi sampel, kemudian dikompilasi dan diolah menjadi data penelitian.

Karakteristik Responden. Karakteristik responden dimaksudkan untuk mengidentifikasi responden, sehingga lebih memudahkan dalam penganalisaan dan memudahkan pemahaman atas objek dan subjek penelitian. Karakteristik responden dalam penelitian adalah sebagai berikut:

Karakteristik Responden Berdasarkan Jenis Kelamin. Adapun responden berdasarkan jenis kelamin dapat dilihat pada Tabel 1.

Tabel 1. Karakteristik Responden Berdasarkan Jenis Kelamin

\begin{tabular}{cccc}
\hline No. & Jenis Kelamin & $\begin{array}{c}\text { Jumlah Responden } \\
\text { ( Orang ) }\end{array}$ & $\begin{array}{c}\text { Persentase } \\
(\%)\end{array}$ \\
\hline 1 & Laki-Laki & - & - \\
2 & Perempuan & 35 & 100 \\
& Jumlah & 35 & 100 \\
\hline
\end{tabular}

Sumber: Data Primer diolah

Berdasarkan hasil kuesioner yang disebarkan dapat dilihat bahwa responden yang berjenis kelamin laki-laki sebanyak 0 orang dengan tingkat persentase $0 \%$ dan responden berjenis kelamin perempuan sebanyak 35 orang dengan tingkat persentase $100 \%$.

Karakteristik Responden Berdasarkan Pendidikan. Karakteristik responden berdasarkan pendidikan dapat dilihat pada Tabel 2.

Menurut Tabel 2 dapat dilihat bahwa responden dengan tingkat pendidikan S1/D3 sebesar $11,43 \%$ atau sebanyak 4orang sedangkan tingkat pendidikan SMA sebesar 88,57 \% atau 31responden. 
Tabel 2. Karakteristik Responden Berdasarkan Pendidikan

\begin{tabular}{cccc}
\hline No. & Pendidikan & $\begin{array}{c}\text { Jumlah Responden } \\
\text { ( Orang) }\end{array}$ & $\begin{array}{c}\text { Persentase } \\
(\%)\end{array}$ \\
\hline 1 & S1/D3 & 4 & 11,43 \\
2 & SMA & 31 & 88,57 \\
3 & SMP & - & - \\
4 & SD & - & - \\
& Jumlah & 35 & 100 \\
\hline
\end{tabular}

Sumber: Data Primer Diolah

Karakteristik Responden Berdasarkan Usia. Karakteristik responden berdasarkan usia telah penulis kelompokkan dan dapat dilihat pada tabel di bawah ini:

Tabel 3. Karakteristik Responden Berdasarkan Usia

\begin{tabular}{cccc}
\hline No. & Usia & $\begin{array}{c}\text { Jumlah Responden } \\
\text { ( Orang ) }\end{array}$ & $\begin{array}{c}\text { Persentase } \\
(\%)\end{array}$ \\
\hline 1 & <20Tahun & 7 & $20 \%$ \\
2 & 20-30 Tahun & 28 & $80 \%$ \\
3 & 30-40 Tahun & - & - \\
4 & $>$ 40 Tahun & - & - \\
& Jumlah & 35 & $100 \%$ \\
\hline
\end{tabular}

Sumber: Data Primer Diolah

Tabel 3 di atas menunjukan bahwa jumlah sampel yang paling banyak adalah berusia 2030 tahun dengan persentase $80 \%$ di ikuti sampel dengan usia<20 tahun dengan persentase $20 \%$.

Karakteristik Responden Berdasarkan Status Karyawan. Karakteristik responden berdasarkan Status Karyawan telah penulis kelompokkan dan dapat dilihat pada tabel di bawah ini:

Tabel 4. Karakteristik responden berdasarkan StatusKaryawan

\begin{tabular}{cccc}
\hline No & Status pekrjaan & Jumlah Responden (Orang) & Presentase (\%) \\
\hline 1 & Tetap & 7 & 20 \\
2 & Pkwt & 9 & 25,71 \\
3 & Kontrak & 19 & 54,29 \\
Jumlah & & 35 & 100 \\
\hline
\end{tabular}

Sumber: Data Primer Diolah

Tabel 4 di atas menunjukan bahwa sampel status pekerjaan yang paling banyak adalah karyawan Kontrak sebanyak 19 orang dengan persentase 54,29\% di ikuti dengan sampel status pekerjaan Karyawan Pkwt sebanyak 9 orang dengan persentase 25,71\% sedangkan status pekerjaan Karyawan Tetap sebanyak 7 orang dengan persentase $20 \%$.

Karakteristik Responden Berdasarkan Status Pernikahan. Karakteristik sampel berdasarkan Status Pernikahan dapat dilihat berkala pada Tabel 5.

Tabel 5 berikut menunjukan bahwa jumlah sampel yang paling banyak adalah karyawan yang belum menikah sebanyak 30 orang dengan persentase $85,71 \%$ dan yang berstatus karyawan sudah menikah sebanyak 5 orang dengan persentase 14,29\%. 
Tabel 5. Karakteristik responden berdasarkanstatus Pernikahan

\begin{tabular}{cccc}
\hline No & Jenis Status & Jumlah Responden (Orang) & $\begin{array}{c}\text { Presentase } \\
(\%)\end{array}$ \\
\hline 1 & Menikah & 5 & 14,29 \\
2 & BelumMenikah & 30 & 85,71 \\
Jumlah & & & 100 \\
\hline
\end{tabular}

Sumber: Data Primer Diolah

Uji Validitas dan Reliabilitas. Uji Validitas dan Reliabilitas Gaya Kepemimpinan (X1)

Tabel 6. Hasil Uji Validitas Gaya Kepemimpinan ( $\left.\mathrm{X}_{1}\right)$

\begin{tabular}{|c|c|c|c|c|c|}
\hline \multicolumn{6}{|c|}{ Item-Total Statistics } \\
\hline $\begin{array}{l}\text { No } \\
\text { Responden }\end{array}$ & $\begin{array}{l}\text { Scale Mean if } \\
\text { Item Deleted }\end{array}$ & $\begin{array}{l}\text { Scale Variance } \\
\text { if Item Deleted }\end{array}$ & $\begin{array}{l}\text { Corrected } \\
\text { Item-Total } \\
\text { Correlation }\end{array}$ & $\begin{array}{l}\text { Cronbach's } \\
\text { Alpha if Item } \\
\text { Deleted }\end{array}$ & Keterangan \\
\hline $\mathrm{X} 1$ & 49,43 & 30,134 & ,751 & ,861 & Valid \\
\hline $\mathrm{X} 2$ & 49,26 & 34,903 & ,540 & ,872 & Valid \\
\hline X3 & 49,83 & 34,793 & ,555 & ,872 & Valid \\
\hline X4 & 48,91 & 35,963 & ,579 & ,872 & Valid \\
\hline X5 & 49,74 & 36,138 & ,341 & ,882 & Valid \\
\hline X6 & 49,83 & 35,205 & 600 & 871 & Valid \\
\hline $\mathrm{X} 7$ & 49,43 & 30,134 & ,751 & ,861 & Valid \\
\hline $\mathrm{X} 8$ & 49,80 & 36,459 & ,419 & 877 & Valid \\
\hline X9 & 49,23 & 35,182 & ,495 & ,874 & Valid \\
\hline X10 & 49,43 & 30,134 & ,751 & ,861 & Valid \\
\hline X11 & 51,06 & 36,820 & ,411 & ,878 & Valid \\
\hline X12 & 51,06 & 36,820 & ,411 & ,878 & Valid \\
\hline X13 & 50,89 & 36,457 & ,502 & ,875 & Valid \\
\hline X14 & 50,86 & 36,420 & ,522 & ,874 & Valid \\
\hline $\mathrm{X} 15$ & 50,86 & 36,420 &, 522 & ,874 & Valid \\
\hline
\end{tabular}

Berdasarkan hasil outputSPSSversi 21 dapat dilihat pada corrected item-total correlations, inilah nilai korelasi yang diperoleh. Selanjutnya untuk dapat diputuskan instrumen tersebut valid atau tidak, maka nilai tersebut dibandingkan dengan nilai $r_{\text {tabel. }}$. Dengan $n-2$ $=35-2=33$ dengan tingkat Signifikan 0,05 maka didapat $r_{\text {tabel }}$ sebesar 0,3388. Karena

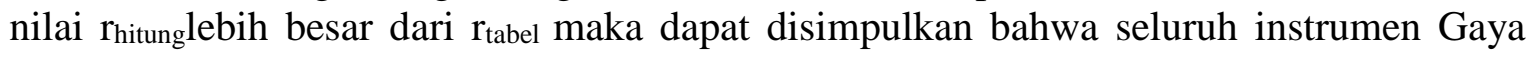
Kepemimpinan $\left(\mathrm{X}_{1}\right)$ mempunyai nilai yang valid. Sehingga dapat digunakan sebagai bahan pengujian selanjutnya. Hasil output reliabilitas Gaya Kepemimpinanadalah sebagai berikut:

Tabel 7. Hasil Uji Reliabilitas Gaya Kepemimpinan $\left(\mathrm{X}_{1}\right)$

\section{Reliability Statistics}

\begin{tabular}{|c|c|}
\hline Cronbach's Alpha & $\mathrm{N}$ of Items \\
\hline 880 & 15 \\
\hline
\end{tabular}

Hasil yang diperoleh adalah $\alpha=0,880$. Jika dilihat dari hasil perhitungan ini adalah lebih dari 0,6 maka disimpulkan bahwa instrumen Gaya Kepemimpinan dapat dikatakan reliabel. 


\section{Uji Validitas dan Reliabilitas Kedisiplinan ( $\left.\mathbf{X}_{2}\right)$}

Tabel 8. Hasil Uji Validitas Kedisiplinan $\left(\mathrm{X}_{2}\right)$

Item-Total Statistics

\begin{tabular}{lrrrrr}
\hline $\begin{array}{l}\text { No } \\
\text { Responden }\end{array}$ & $\begin{array}{c}\text { Scale Mean if } \\
\text { Item Deleted }\end{array}$ & $\begin{array}{c}\text { Scale Variance } \\
\text { if Item Deleted }\end{array}$ & $\begin{array}{c}\text { Corrected } \\
\text { Item-Total } \\
\text { Correlation }\end{array}$ & $\begin{array}{c}\text { Cronbach's } \\
\text { Alpha if Item } \\
\text { Deleted }\end{array}$ & Keterangan \\
\hline X1 & 53,69 & 19,810 &, 625 &, 866 & Valid \\
X2 & 53,77 & 19,770 &, 524 &, 870 & Valid \\
X3 & 53,77 & 19,770 &, 524 &, 870 & Valid \\
X4 & 53,69 & 19,810 &, 625 &, 866 & Valid \\
X5 & 53,89 & 19,987 &, 531 &, 870 & Valid \\
X6 & 53,83 & 19,911 &, 485 &, 872 & Valid \\
X7 & 54,09 & 20,316 &, 442 &, 874 & Valid \\
X8 & 53,89 & 19,987 &, 531 &, 870 & Valid \\
X9 & 54,26 & 19,020 &, 432 &, 881 & Valid \\
X10 & 53,69 & 19,810 &, 625 &, 866 & Valid \\
X11 & 55,66 & 19,644 &, 689 &, 864 & Valid \\
X12 & 55,69 & 20,516 &, 449 &, 873 & Valid \\
X13 & 55,66 & 20,291 &, 521 &, 870 & Valid \\
X14 & 55,66 & 19,644 &, 689 &, 864 & Valid \\
X15 & 56,00 & 20,294 &, 479 &, 872 & Valid \\
\hline
\end{tabular}

Berdasarkan hasil outputSPSSversi 21 dapat dilihat pada corrected item-total correlations, inilah nilai korelasi yang diperoleh. Selanjutnya untuk dapat diputuskan instrumen tersebut valid atau tidak, maka nilai tersebut dibandingkan dengan nilai $r_{\text {tabel. }}$ Dengan $n-2$ $=35-2=33$ dengan tingkat Signifikan0,05 maka didapat $r_{\text {tabel }}$ sebesar 0,3388. Karena nilai $\mathrm{r}_{\text {hitung }}$ lebih besar dari $\mathrm{r}_{\text {tabel }}$ maka dapat disimpulkan bahwa seluruh instrumen Kedisiplinan $\left(\mathrm{X}_{2}\right)$ mempunyai nilai yang valid. Sehingga dapat digunakan sebagai bahan pengujian selanjutnya. Hasil output reliabilitas Kedisiplinanadalah sebagai berikut:

Tabel 9. Hasil Uji Reliabilitas Kedisplinan $\left(\mathrm{X}_{2}\right)$

Reliability Statistics

\begin{tabular}{rrr}
\hline Cronbach's Alpha & N of Items & \\
\hline, 877 & & 15 \\
\hline
\end{tabular}

Hasil yang diperoleh adalah $\alpha=0,877$. Jika dilihat dari hasil perhitungan ini adalah lebih dari 0,6 maka disimpulkan bahwa instrumen Kedisiplinan dapat dikatakan reliabel.

Uji Validitas dan Reliabilitas Kinerja Karyawan (Y). Berdasarkan Tabel 10 hasil outputSPSS versi 21dapat dilihat pada corrected item-total correlations, inilah nilai korelasi yang diperoleh. Selanjutnya untuk dapat diputuskan instrumen tersebut valid atau tidak, maka nilai tersebut dibandingkan dengan nilai $r_{\text {tabel. }}$. Dengan $n-2=35-2=33$ dengan tingkat Signifikan0,05 maka didapat $\mathbf{r}_{\text {tabel }}$ sebesar 0,3388. Karena nilai $r_{\text {hitunglebih besar dari }}$ $\mathrm{r}_{\text {tabel }}$ maka dapat disimpulkan bahwa instrumen Kinerja Karyawan (Y) mempunyai nilai valid sehingga dapat digunakan sebagai bahan pengujian selanjutnya. 
Tabel 10. Hasil Uji Validitas Kinerja Karyawan (Y)

Item-Total Statistics

\begin{tabular}{lrrrrl}
\hline $\begin{array}{l}\text { No } \\
\text { Responden }\end{array}$ & $\begin{array}{r}\text { Scale Mean if } \\
\text { Item Deleted }\end{array}$ & $\begin{array}{c}\text { Scale Variance } \\
\text { if Item Deleted }\end{array}$ & $\begin{array}{c}\text { Corrected } \\
\text { Item-Total } \\
\text { Correlation }\end{array}$ & $\begin{array}{c}\text { Cronbach's } \\
\text { Alpha if Item } \\
\text { Deleted }\end{array}$ & Keterangan \\
\hline Y1 & 50,37 & 24,123 &, 536 &, 864 & Valid \\
Y2 & 50,46 & 25,255 &, 402 &, 870 & Valid \\
Y3 & 50,09 & 22,845 &, 639 &, 858 & Valid \\
Y4 & 49,97 & 23,264 &, 818 &, 849 & Valid \\
Y5 & 50,49 & 25,787 &, 343 &, 873 & Valid \\
Y6 & 49,66 & 25,703 &, 409 &, 869 & Valid \\
Y7 & 49,91 & 25,434 &, 504 &, 865 & Valid \\
Y8 & 49,71 & 25,151 &, 577 &, 862 & Valid \\
Y9 & 50,09 & 22,845 &, 639 &, 858 & Valid \\
Y10 & 49,97 & 23,264 &, 818 &, 849 & Valid \\
Y11 & 51,49 & 26,198 &, 412 &, 869 & Valid \\
Y12 & 51,51 & 25,963 &, 449 &, 867 & Valid \\
Y13 & 51,49 & 25,845 &, 490 &, 866 & Valid \\
Y14 & 51,77 & 26,064 &, 395 &, 869 & Valid \\
Y15 & 51,83 & 25,970 &, 427 &, 868 & Valid \\
\hline
\end{tabular}

Hasil output reliabilitas Kinerja Karyawan adalah sebagai berikut.

Tabel 11. Hasil Uji Reliabilitas Kinerja Karyawan (Y)

Reliability Statistics

\begin{tabular}{cc}
\hline Cronbach's Alpha & N of Items \\
\hline, 872 & 15 \\
\hline
\end{tabular}

Hasil yang diperoleh adalah $\alpha=0,872$. Jika dilihat dari hasil perhitungan ini adalah lebih dari 0,6 maka disimpulkan bahwa instrumen Kinerja Karyawan dapat dikatakan reliabel.

Uji Asumsi Klasik. Uji Normalitas. Uji Normalitas Variabel Gaya Kepemimpinan $\left(\mathrm{X}_{1}\right)$. Uji normalitas dilakukan untuk mengetahui apakah data yang diteliti berdistribusi normal atau tidak.

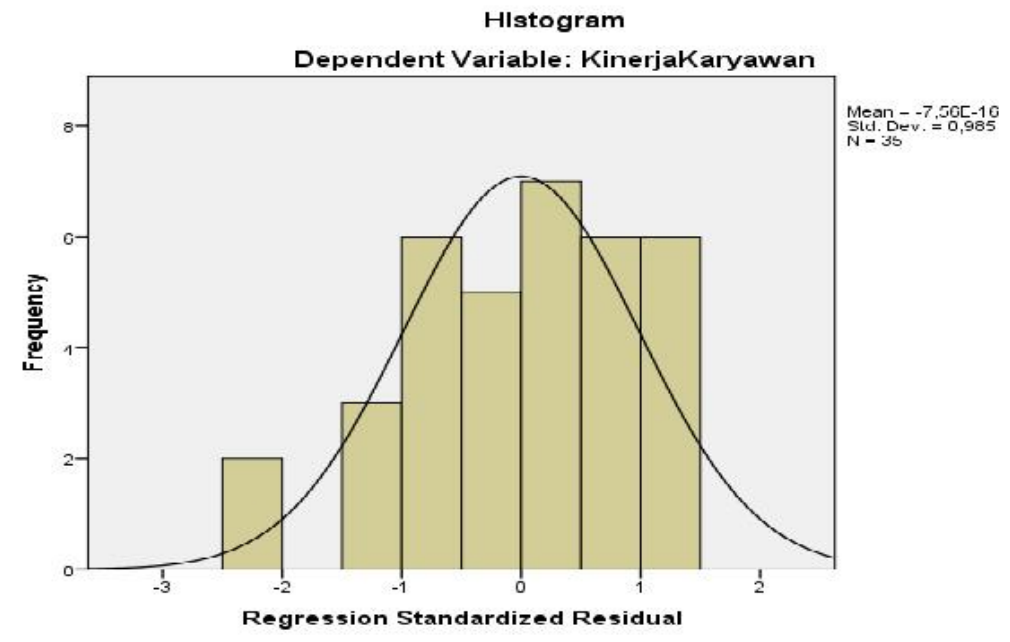


Adanya normalitas adalah dengan melihat penyebaran titik-titik pada sumbu diagonal dari grafik. Berdasarkan hasil perhitungan SPSS versi 21 diperoleh hasil uji normalitas data sebagaimana ditunjukkan pada grafik histogram dan grafik normal P. Plot sebagai berikut:

\section{Uji Multikolinearitas}

Tabel 12. Uji Multikolinearitas

\begin{tabular}{llcr}
\multicolumn{4}{c}{ Coefficients $^{\mathbf{a}}$} \\
\hline \multirow{2}{*}{ Model } & \multicolumn{2}{c}{ Collinearity Statistics } \\
\cline { 3 - 4 } & & Tolerance & VIF \\
\hline \multirow{2}{*}{1} & GayaKepemimpinan &, 748 & 1,336 \\
& Kedisiplinan &, 748 & 1,336 \\
\hline
\end{tabular}

a. Dependent Variable: KinerjaKaryawan

Berdasarkan Tabel coefficient 12 menunjukkan bahwa nilai Variance Inflation Factor (VIF) variabel Gaya Kepemimpinan $\left(\mathrm{X}_{1}\right)$ dan variabel Kedisiplinan $\left(\mathrm{X}_{2}\right)$ adalah 1,336 yang berarti nilai Variance Inflation Factor $(\mathrm{VIF})<10$. Dilihat dari nilai tolerancedari kedua variabel adalah 0,748 yang berarti nilai tolerance $<1$. Dengan demikian dari hasil pengolahan dengan SPSS versi 21 tersebut dapat disimpulkan bahwa dalam penelitian ini tidak ada gejala multikolinearitas.

Uji Heteroskedastisitas. Uji heteroskedastisitas digunakan untuk mengetahui tidak adanya penyimpangan asumsi klasik heteroskedastisitas, yaitu adanya ketidasamaan varian dari residual untuk semua pengamatan pada model regresi. Untuk mengetahui ada tidaknya gejala heteroskedastisitas, maka dapat dilakukan dengan melihat ada tidaknya pola tertentu pada grafik scatterplot, dengan dasar analisis sebagai berikut: (a) Jika ada pola tertentu, seperti titik-titik yang ada membentuk pola tertentu yang teratur (bergelombang, melebar kemudian menyempit), maka mengindikasikan telah terjadi heteroskedastisitas; (b) Jika tidak ada pola yang jelas, secara titik-titik menyebar di atas dan di bawah 0 maka tidak terjadi heteroskedastisitas. Berikut ini grafik scatterplot yang akan menunjukkan ada atau tidaknya gejala heteroskedastisitas adalah sebagai berikut:

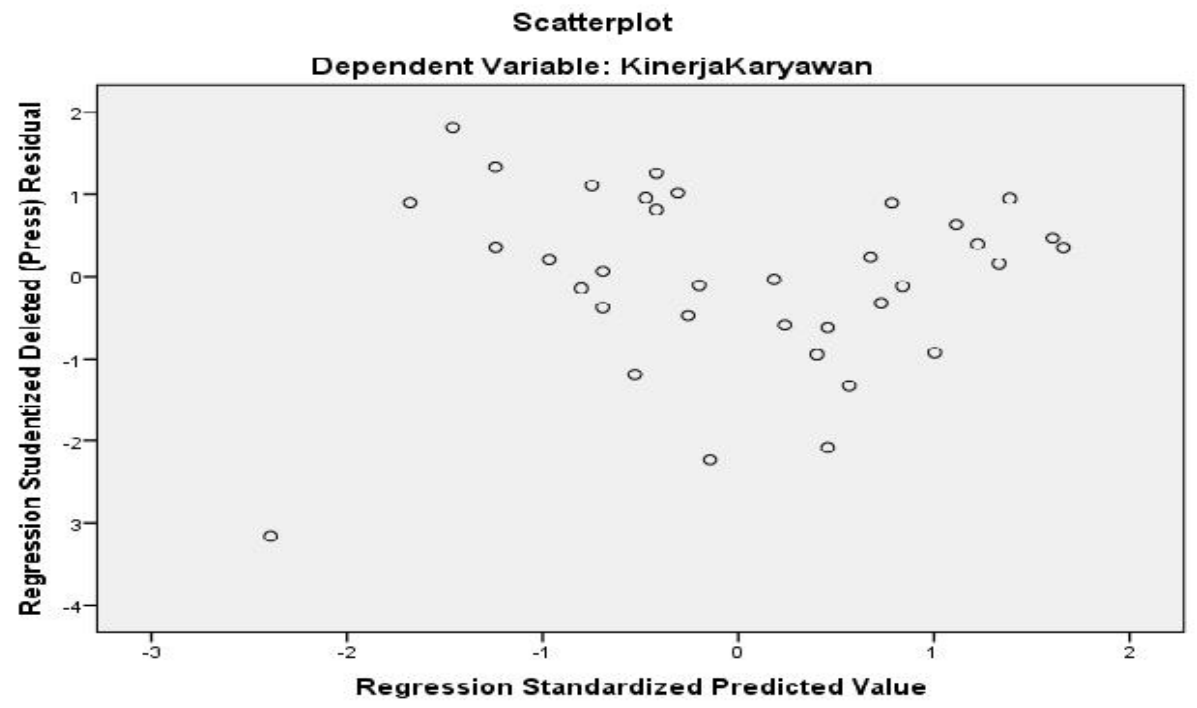

Grafik 3. Uji Heteroskedastisitas 
Dari scatterplot di atas terlihat bahwa titik-titik menyebar secara acak serta tersebar di atas dan di bawah 0 . Hal ini dapat dapat disimpulkan bahwa tidak terjadi heteroskedastisitas pada model regresi.

\section{Pengujian Hipotesis Secara Simultan Variabel Gaya Kepemimpinan $\left(\mathrm{X}_{1}\right)$ dan Kedisiplinan( $\left.\mathbf{X}_{2}\right)$ Terhadap Kinerja Karyawan (Y)}

Uji F. Uji F bertujuan untuk melihat pengaruh variabel bebas yaitu Gaya Kepemimpinan dan Kedisiplinan secara simultan atau bersama-sama terhadap Kinerja Karyawan seperti ditunjukkan pada Tabel 13.

Tabel 13. Hasil Uji-F

\begin{tabular}{rlrrrrr}
\multicolumn{7}{c}{ ANOVA $^{\text {a }}$} \\
\hline Model & & Sum of & df & Mean Square & F & Sig. \\
& Squares & & & & & \\
\multirow{2}{*}{1} & Regression & 794,120 & 2 & 397,060 & 74,970 &, $000^{\mathrm{b}}$ \\
& Residual & 169,480 & 32 & 5,296 & & \\
\hline & Total & 963,600 & 34 & & & \\
\hline
\end{tabular}

a. Dependent Variable: KinerjaKaryawan

b. Predictors: (Constant), Kedisiplinan, GayaKepemimpinan

Berdasarkan Tabel 13 dapat diketahui bahwa nilai $f_{\text {hitung }}$ yaitu 74,970. Sedangkan menentukan $\mathrm{f}_{\text {tabel }}$ dengan tingkat keyakinan $(\alpha)$ yaitu $=0,05$. Derajat kebebasan/degree of freedom (df), df $1=\mathrm{k}-1=3-1=2$, df $2=\mathrm{n}-\mathrm{k}=35-3=32$. Maka nilai $\mathrm{f}_{\text {tabel }}$ yaitu 3,29.

Merumuskan hipotesis statistik adalah sebagai berikut:

$\mathrm{H}_{\mathrm{o}}: \beta_{1}, \beta_{2}=\mathbf{0}$, tidak ada pengaruh Gaya Kepemimpinan $\left(\mathrm{X}_{1}\right)$ dan Kedisiplinan $\left(\mathrm{X}_{2}\right)$ secara simultan terhadap Kinerja Karyawan.

$\mathrm{H}_{\mathrm{a}}: \beta_{1} \beta_{\mathbf{2}} \neq \mathbf{0}$, ada pengaruh Gaya Kepemimpinan $\left(\mathrm{X}_{1}\right)$ dan Kedisiplinan $\left(\mathrm{X}_{2}\right)$ secara simultan terhadap Kinerja Karyawan.

Karena nilai $\mathrm{f}_{\text {hitung }}>\mathrm{f}_{\text {tabel }}(74,970>3,29)$ maka $\mathrm{H}_{\mathrm{o}}$ ditolak dan $\mathrm{H}_{\mathrm{a}}$ diterima. Berdasarkan uji signifikansi diperoleh bahwa secara simultan terdapat pengaruh antara Gaya Kepemimpinan dan Kedisiplinan terhadap Kinerja Karyawan di PT.BANK BTPN Syari'ah,Tbk Cabang Serang.

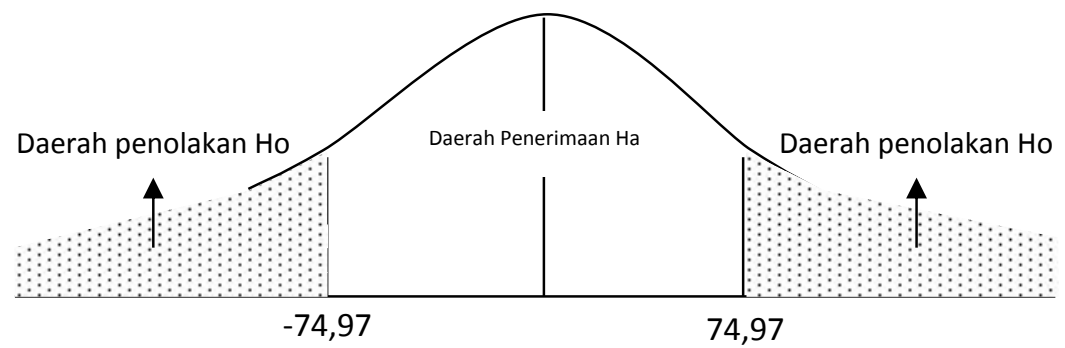

Gambar 4. Daerah Pengujian Uji-f Gaya Kepemimpinan dan Kedisiplinan Terhadap Kinerja Karyawan

Uji Koefisien Kolerasi Berganda. Untuk mengetahui tingkat hubungan dari Gaya Kepemimpinan $\left(\mathrm{X}_{1}\right)$ dan Kedisiplinan $\left(\mathrm{X}_{2}\right)$ terhadap Kinerja Karyawan( $\left.\mathrm{Y}\right)$ dapat dilihat dari tabel output korelasi pearson di bawah ini: 
Tabel 14. Korelasi Gaya Kepemimpinan $\left(X_{1}\right)$ dan Kedisiplinan $\left(X_{2}\right)$ Terhadap Kinerja Karyawan (Y)

\begin{tabular}{lcrrr}
\multicolumn{5}{c}{ Model Summary $^{\mathbf{b}}$} \\
\hline Model & R & R Square & $\begin{array}{c}\text { Adjusted R } \\
\text { Square }\end{array}$ & $\begin{array}{c}\text { Std. Error of the } \\
\text { Estimate }\end{array}$ \\
\hline 1 &, $908^{\mathrm{a}}$ &, 824 &, 813 & 2,301 \\
\hline
\end{tabular}

a. Predictors: (Constant), Kedisiplinan, GayaKepemimpinan

b. Dependent Variable: KinerjaKaryawan

Berdasarkan Tabel 14 di atas nilai koefisien korelasi antara Gaya Kepemimpinan dan Kedisiplinan terhadap Kinerja Karyawan sebesar 0.908. Dengan demikian dapat disimpulkan bahwa antara Gaya Kepemimpinan $\left(\mathrm{X}_{1}\right)$ dan Kedisiplinan $\left(\mathrm{X}_{2}\right)$ terhadap Kinerja Karyawan (Y) mempunyai hubungan yang sangat kuat dan 0.908 berada pada interval koefisien $0,80-1.000$.

Uji Koefisien Determinasi Simultan. Untuk mengetahui besarnya kontribusi variabel Gaya Kepemimpinan $\left(\mathrm{X}_{1}\right)$ dan Kedisiplinan $\left(\mathrm{X}_{2}\right)$ terhadap variabel Kinerja Karyawan $(\mathrm{Y})$ yang dinyatakan dalam persentase dan dapat diketahui melalui koefisien determinasi. Hal ini dapat dilihat dari model summary yang dihasilkan dengan menggunakan software SPSS versi 21.

Tabel 15. Koefisien Determinasi Gaya Kepemimpinan $\left(\mathrm{X}_{1}\right)$ dan Kedisiplinan

$\left(\mathrm{X}_{2}\right)$ Terhadap Kinerja Karyawan $(\mathrm{Y})$

\section{Model Summary ${ }^{b}$}

\begin{tabular}{lrrrrr}
\hline Model & R & R Square & $\begin{array}{c}\text { Adjusted R } \\
\text { Square }\end{array}$ & \multicolumn{2}{c}{$\begin{array}{c}\text { Std. Error of the } \\
\text { Estimate }\end{array}$} \\
\hline 1 &, $908^{\mathrm{a}}$ &, 824 &, 813 & 2,301 \\
\hline
\end{tabular}

a. Predictors: (Constant), Kedisiplinan, GayaKepemimpinan

b. Dependent Variable: KinerjaKaryawan

Berdasarkan Tabel 15 dapat diketahui bahwa nilai koefisien determinasi $\left(\mathrm{R}^{2}\right)$ sebesar 0,824 . Selanjutnya digunakan perhitungan koefisien determinasi (KD) untuk mengetahui besarnya pengaruh variabel Gaya Kepemimpinan dan Kedisiplinan terhadap Kinerja Karyawan.

$$
\begin{aligned}
\mathrm{KD} & =\mathrm{R}^{2} \times 100 \% \\
\mathrm{KD} & =0.908^{2} \times 100 \% \\
& =0.824 \times 100 \% \\
& =82,4 \%
\end{aligned}
$$

Hal ini dapat disimpulkan bahwa Gaya Kepemimpinan $\left(\mathrm{X}_{1}\right)$ dan Kedisiplinan $\left(\mathrm{X}_{2}\right)$ memberikan kontribusi sebesar 82,4\% terhadap Kinerja Karyawan (Y), sedangkan sisanya $17,6 \%$ dipengaruhi variabel lain yang tidak dibahas dalam penelitian ini.

Pembahasan. Berdasarkan hasil pengujian secara statistik dapat terlihat dengan jelas bahwa secara parsial (sendiri-sendiri) maupun simultan (bersama-sama) variabel bebas berpengaruh terhadap variabel terikat. Hasil penelitian ini juga sesuai dengan hasil penelitian sebelumnya. Penjelasan dari masing-masing pengaruh variabel dijelaskan sebagai berikut: 
1. Pengujian Hipotesis secara parsialVariabel Gaya Kepemimpinan (X1) Terhadap Kinerja Karyawan (Y). Hal ini dibuktikan dari hasil perhitungan SPSS versi 21 yaitu nilai $\mathrm{t}$-hitung sebesar 5,172 dan $\mathrm{t}$-tabel sebesar 2,03693, menunjukkan bahwa Karena nilai $t_{\text {hitung }}>\mathrm{t}_{\text {tabel }}(5,172>2,03693)$ maka $\mathrm{H}_{\mathrm{o}}$ ditolak dan $\mathrm{H}_{\mathrm{a}}$ diterima. Berdasarkan uji signifikansi diperoleh bahwa terdapat pengaruh antara Gaya Kepemimpinan terhadap Kinerja Kerja Karyawan pada PT.BANK BTPN Syari'ah,Tbk Cabang Serang.

Hasil penelitian ini mendukung hasil penelitian sebelumnya yang dilakukan oleh Sindu Pradipto yang berjudul Analisis Pengaruh Gaya Kepemimpinan Dan Disiplin Kerja Terhadap Kinerja Pegawai, Dengan Motivasi Kerja Sebagai Variabel Intervening (Studi Pada Dinas Pendidikan Provinsi Jawa Tengah).

2. Pengujian Hipotesis secara parsialVariabel Gaya Kepemimpinan (X1) Terhadap Kinerja Karyawan (Y). Hal ini dibuktikan dari hasil perhitungan SPSS versi 21 yaitu nilai koefisien korelasi antara Gaya Kepemimpinan Terhadap Kinerja Karyawan sebesar 0,669. Dengan demikian dapat disimpulkan bahwa antara Gaya Kepemimpinan (X1) terhadap Kinerja Karyawan (Y) mempunyai hubungan yang kuat dan 0,669 berada pada interval koefisien 0.60 - 0,799 (kuat). Nilai koefisien Determinasi $\left(\mathrm{R}^{2}\right)$ Sebesar 0,448, artinya bahwa Gaya Kepemimpinan (X1) Memberikan kontribusi sebesar 44,8\% terhadap kinerja karyawan (Y), sedangkan sisanya 55,2\% dipengaruhi variabel lain yang tidak dibahas dalam penelitian.

3. Pengujian Hipotesis secara parsialVariabel Kedisiplinan(X2) Terhadap Kinerja Karyawan (Y). Hal ini dibuktikan dari hasil perhitungan SPSS versi 21 yaitu nilai thitung sebesar 9,968dan t-tabel sebesar 2,03693, menunjukkan bahwa Karena nilai thitung $>$ $t_{\text {tabel }}\left(9,968>2,03693\right.$ ) maka $\mathrm{H}_{\mathrm{o}}$ ditolak dan $\mathrm{H}_{\mathrm{a}}$ diterima.Berdasarkan uji signifikansi diperoleh bahwa terdapat pengaruh antara Kedisiplinan terhadap Kinerja Kerja Karyawan pada PT.BANK BTPN Syari'ah,Tbk Cabang Serang.

Hasil penelitian ini mendukung hasil penelitian sebelumnya yang dilakukan oleh Bryan Johannes Tampi yang berjudul Pengaruh Gaya Kepemimpinan Dan Motivasi Terhadap Kinerja Karyawan Pada PT.Bank Negara Indonesia,Tbk (Regional Manado).

4. Pengujian Hipotesis secara parsialVariabel Kedisiplinan (X2) terhadap Kinerja Karyawan (Y). Hal ini dibuktikan dari hasil perhitungan SPSS versi 21 yaitu nilai koefisien korelasi antara Gaya Kepemimpinan Terhadap Kinerja Karyawan sebesar 0,866. Dengan demikian dapat disimpulkan bahwa antara Kedisiplinan (X2) terhadap Kinerja Karyawan (Y) mempunyai hubungan yang kuat dan 0,866 berada pada interval koefisien 0.80 - 1.000 ( sangat kuat). Nilai koefisien Determinasi $\left(\mathrm{R}^{2}\right)$ Sebesar 0,751, artinya bahwa Gaya Kepemimpinan (X1) Memberikan kontribusi sebesar 75,1\% terhadap kinerja karyawan (Y), sedangkan sisanya 24,9\% dipengaruhi variabel lain yang tidak dibahas dalam penelitian.

5. Pengujian Hipotesis secara simultanVariabel Gaya Kepemimpinan (X1) dan Kedisiplinan (X2) Terhadap Kinerja Karyawan (Y). Hal ini dibuktikan dari hasil perhitungan SPSS versi 21 yaitu nilai t-hitung sebesar 74,970 dan t-tabel sebesar 2,03693, menunjukkan bahwa Karena nilai $t_{\text {hitung }}>t_{\text {tabel }}(74,970>2,03693)$ maka $\mathrm{H}_{\mathrm{o}}$ ditolak dan $\mathrm{H}_{\mathrm{a}}$ diterima. Berdasarkan uji signifikansi diperoleh bahwa terdapat pengaruh antara Gaya Kepemimpinan dan Kedisiplinan terhadap Kinerja Kerja Karyawan pada PT.BANK BTPN Syari'ah,Tbk Cabang Serang. 
Hasil penelitian ini mendukung hasil penelitian sebelumnya yang dilakukan oleh Titin Syang berjudul Pengauh Gaya Kepemimpinan Terhadap Kinerja Karyawan Pada SBU Pos Prima Direktorat Operasi PT.Pos Indonesia (Persero).

6. Pengujian Hipotesis secara SimultanVariabel Gaya Kepemimpinan (X1) dan Kedisiplinan (X2) Terhadap Kinerja Karyawan (Y). Hal ini dibuktikan dari hasil perhitungan SPSS versi 21 yaitu nilai koefisien korelasi antara Gaya Kepemimpinan (X1) dan Kedisiplinan (X2) Terhadap Kinerja Karyawan (Y) sebesar 0,908. Dengan demikian dapat disimpulkan bahwa antara Gaya Kepemimpinan (X1) dan Kedisiplinan (X2) terhadap Kinerja Karyawan (Y) mempunyai hubungan yang sangat kuat dan 0,908 berada pada interval koefisien $0.80-1.000$ (sangat kuat). Nilai koefisien Determinasi $\left(\mathrm{R}^{2}\right)$ Sebesar 0,824, artinya bahwa Gaya Kepemimpinan (X1) dan Kedisiplinan (X2) Memberikan kontribusi sebesar 82,4\% terhadap kinerja karyawan (Y), sedangkan sisanya $17,6 \%$ dipengaruhi variabel lain yang tidak dibahas dalam penelitian.

\section{PENUTUP}

Simpulan. Berdasarkan hasil penelitian dari Gaya Kepemimpinan dan Tingkat Kedisiplinan terhadap Kinerja Karyawan di Unit PT.BANK BTPN Syari'ah,Tbk Cabang Serang, dan setelah diadakan pengujian hipotesis terhadap permasalahan yang ada pada skripsi ini, maka dapat mengambil kesimpulan sebagai berikut:

1. Berdasarkan uji signifikansi diperoleh bahwa terdapatpengaruh antara Gaya Kepemimpinan (X1) Terhadap Kinerja Karyawan (Y). Hal ini dibuktikan dari hasil perhitungan SPSS versi 21 yaitu nilai t-hitung sebesar 5,172 dan t-tabel sebesar 2,03693, menunjukkan bahwa Karena nilai $t_{h i t u n g}>t_{\text {tabel }}(5,172>2,03693)$ maka $H_{o}$ ditolak dan $\mathrm{H}_{\mathrm{a}}$ diterima.

2. Presentase seberapa besar Gaya Kepemimpinan (X1) berpengaruh Terhadap Kinerja Karyawan (Y) pada PT.BANK BTPN Syari' ah,Tbk Cabang Serang. Hal ini dibuktikan dari hasil perhitungan SPSS versi 21 yaitu nilai koefisien korelasi antara Gaya Kepemimpinan Terhadap Kinerja Karyawan sebesar 0,669. Dengan demikian dapat disimpulkan bahwa antara Gaya Kepemimpinan (X1) terhadap Kinerja Karyawan (Y) mempunyai hubungan yang kuat dan 0,669 berada pada interval koefisien $0.60-0,799$ (kuat). Nilai koefisien Determinasi $\left(\mathrm{R}^{2}\right)$ Sebesar 0,448 , artinya bahwa Gaya Kepemimpinan (X1) Memberikan kontribusi sebesar 44,8\% terhadap kinerja karyawan (Y), sedangkan sisanya 55,2\% dipengaruhi variabel lain yang tidak dibahas dalam penelitian.

3. Berdasarkan uji signifikansi diperoleh bahwa terdapatpengaruh antaraKedisiplinan (X2) Terhadap Kinerja Karyawan (Y). Hal ini dibuktikan dari hasil perhitungan SPSS versi 21 yaitu nilai t-hitung sebesar 9,968 dan $t$-tabel sebesar 2,03693, menunjukkan bahwa Karena nilai thitung $>t_{\text {tabel }}\left(9,968>2,03693\right.$ ) maka $\mathrm{H}_{\mathrm{o}}$ ditolak dan $\mathrm{H}_{\mathrm{a}}$ diterima.

4. Presentase seberapa besar Kedisiplinan (X2) berpengaruh terhadap Kinerja Karyawan (Y) pada PT.BANK BTPN Syari'ah,Tbk Cabang Serang. Hal ini dibuktikan dari hasil perhitungan SPSS versi 21 yaitu nilai koefisien korelasi antara Gaya Kepemimpinan Terhadap Kinerja Karyawan sebesar 0,866. Dengan demikian dapat disimpulkan bahwa antara Kedisiplinan (X2) terhadap Kinerja Karyawan (Y) mempunyai hubungan yang kuat dan 0,866 berada pada interval koefisien $0.80-1.000$ ( sangat kuat). Nilai koefisien Determinasi $\left(R^{2}\right)$ Sebesar 0,751 , artinya bahwa Gaya 
Kepemimpinan (X1) Memberikan kontribusi sebesar 75,1\% terhadap kinerja karyawan (Y), sedangkan sisanya $24,9 \%$ dipengaruhi variabel lain yang tidak dibahas dalam penelitian.

5. Berdasarkan uji signifikansi diperoleh bahwa terdapatpengaruh antaraGaya Kepemimpinan (X1) dan Kedisiplinan (X2) Terhadap Kinerja Karyawan (Y). Hal ini dibuktikan dari hasil perhitungan SPSS versi 21 yaitu nilai t-hitung sebesar 74,970 dan ttabel sebesar 2,03693, menunjukkan bahwa Karena nilai $t_{\text {hitung }}>t_{\text {tabel }}(74,970>2,03693)$ maka $\mathrm{H}_{\mathrm{o}}$ ditolak dan $\mathrm{H}_{\mathrm{a}}$ diterima.

6. Persentase seberapa besar Gaya Kepemimpinan (X1) dan Kedisiplinan (X2) berpengaruh Terhadap Kinerja Karyawan (Y) pada PT.BANK BTPN Syari'ah,Tbk Cabang Serang. Hal ini dibuktikan dari hasil perhitungan SPSS versi 21 yaitu nilai koefisien korelasi antara Gaya Kepemimpinan (X1) dan Kedisiplinan (X2) Terhadap Kinerja Karyawan (Y) sebesar 0,908. Dengan demikian dapat disimpulkan bahwa antara Gaya Kepemimpinan (X1) dan Kedisiplinan (X2) terhadap Kinerja Karyawan (Y) mempunyai hubungan yang sangat kuat dan 0,908 berada pada interval koefisien $0.80-1.000$ (sangat kuat). Nilai koefisien Determinasi $\left(\mathrm{R}^{2}\right)$ Sebesar 0,824, artinya bahwa Gaya Kepemimpinan (X1) dan Kedisiplinan (X2) Memberikan kontribusi sebesar $82,4 \%$ terhadap kinerja karyawan (Y), sedangkan sisanya 17,6\% dipengaruhi variabel lain yang tidak dibahas dalam penelitian.

Saran. Berdasarkan kesimpulan hasil peneliti tentang dampak pergantian Gaya Kepemimpinan dan Tingkat Kedisiplinan terhadap Kinerja Karyawan di Unit PT.BANK BTPN Syari'ah,Tbk Cabang Serang, maka peneliti mengajukan saran yaitu: (1) Pemimpin Perusahaan masih perlu memberikan pelatihan dan memberikan bonus terhadap karyawan, agar kualitas kerja karyawan meningkat serta dapat mengairahkan kinerja sehingga tujuan perusahaan dapat tercapai; (2) Pemimpin perusahaan lebih memperhatikan karyawan dalam menyelesaikan pekerjaannya sehingga karyawan yang bersangkutan akan bekerja lebih giat lagi dan semangat terus meningkat, perlunya pengawasan terhadap hasil kerja yang lebih ketat selain pimpinan juga sebaiknya menjaga hubungan yang harmonis dengan para bawahannya agar para pekerjanya dapat bekerja dengan lebih tenang dan lebih baik lagi; (3) Secara umum Gaya Kepemimpinan dan Kedisiplinan kerja memberikan pengaruh yang positif terhadap Kinerja Kerja Karyawan pada PT.BANK BTPN Syari'ah,Tbk Cabang Serang, untuk itu disarankan perusahaan memberikan pelatihan khusus bagi para pemimpin-pemimpin nya agar dalam memimpin perusahaan dapat mengaplikasikan Gaya Kepemimpinan dan Kedisiplinan kepada bawahannya sehingga Kinerja Kerja Karyawan, tujuan dan Target BTPN Syari'ah dapat tercapai; (4) Pemimpin perusahaan perlu melakukan usaha untuk meningkatkan komunikasi 2 arah dengan karyawan sehingga karyawan dapat lebih mudah dalam menyampaikan saran serta ide-ide bagi perusahaan, kemudian menjalin hubungan yang baik dengan karyawan itu perlu sebagai contoh sering mengadakan rapat rutin dimana karyawan bisa menyampaikan pendapat dan diikut sertakan dalam pengambilan keputusan; (5) Pemimpin perlu membuat aturan yang jelas mengenai kedisiplinan, dengan memberikan sangsi-sangsi tegas bagi karyawan yang sering terlambat, sering tidak menyelesaikan tugas yang diberikan atasan, maupun yang selalu terlambat setelah jam istirahat. Selain itu, pemimpin perlu melakukan usaha untuk meningkatkan komunikasi yang baik disertai kontrol sehingga karyawan dapat lebih sadar untuk mentaati peraturan yang ada; (6) Hasil penelitian menunjukan bahwa variabel Gaya Kepemimpinan dan Tingkat Kedisiplinan secara simultan memiliki pengaruh yang signifikan terhadap Kinerja Karyawan PT.BANK BTPN Syari'ah,Tbk Cabang Serang. 
Untuk itu ketiga Variabel tersebut perlu mendapatkan perhatian yang lebih baik sehingga kinerja di tahun-tahun mendatang dapat lebih ditingkatkan.

\section{DAFTAR RUJUKAN}

Bryan Johannes Tampi. (2014) "Pengaruh gaya kepemimpinan dan motivasi terhadap kinerja karyawan pada PT.Bank Negara Indonesia,Tbk (Regional Sales Manado). STIMIK AUB Surakarta”. J urnal “Activa Diur” III (4).

Danang Setya Ramadhani. (2016) “Pengaruh Kepemimpinan dan motivasi terhadap kinerja pegawai di balai pengembangan kegiatan belajar (BPKB) Daerah Istimewa Yogyakarta (DIY)". Skripsi, Universitas Negeri Yogyakarta.

Dwi Lestari. (2014) "Pengaruh gaya kepemimpinan,disiplin kerja dan kompensasi terhadap kinerja karyawan pada PT. Nuansa Nirmana Artistika". Skripsi, Binus University.

Harbani Pasolong. (2013) Kepemimpinan Birokrasi. Bandung: Alfabeta.

Karina. (2013) Aplikasi Spss. Serang: STIE Bina Bangsa.

Luis Aparicio Guterres. (2016) "Pengaruh gaya kepemimpinan dan motivasi kerja terhadap kinerja Guru". E-Jurnal Ekonomi dan bisnis Universitas Udayana, Bali Indonesia.

Mangkunegara. (2012) Evaluasi Kinerja SDM. Bandung: PT Refika.

Prabu Mangkunegara A.A.Anwar, (2015) Manajemen Sumber Daya Manusia Perusahaan. Bandung: PT Remaja Rosdakarya.

Sutrisno, Edy. (2016) Manajemen sumber Daya Manusia. Rawamangun-Jakarta: Prenadamedia.

Sugiyono. (2016) Metode Penelitian. Bandung: Alfabeta.

Sugiyono. (2016) Metode Penelitian Kuantitatif, Kualitatif dan R\&D. Bandung: Alfabeta.

Sindu Pradipto. (2015) Analisis pengaruh gaya kepemimpinan dan disiplinkerja pegawai,dengan motivasi kerja sebagai variabel intervening. Universitas Diponegoro.

Titin.S. (2010) "Pengaruh gaya kepemimpinan terhadap kinerja pegawai pada SBU Pos Prima direktorat operasi PT Pos Indonesia (Persero)". Politeknik Bandung. Jurnal Manajemen, 9 (2), Mei 